\title{
A NEW BARBAREA FROM SOUTHWEST ANATOLIA
}

\author{
KIT TAN \& Y. GemICI* \\ Barbarea hedgeana Kit Tan \& Gemici (Cruciferae) is illustrated and described from \\ southwest Anatolia. It is a small perennial marked by a distinct overall fruiting facies.
}

\section{Barbarea hedgeana Kit Tan \& Gemici, sp. nov. Fig. 1.}

Herba perennis parva; caudex \pm horizontalis, lignosus, reliquiis petiolaribus fibrosis vestitus. Caulis florifer erectus, unicus, simplex vel sparse ramosus, $7-14 \mathrm{~cm}$ altus, glaber. Folia basalia longe petiolata, rosulam distinctam formantia; lamina simplex, ovata, c. $7-10 \times 5-7 \mathrm{~mm}$, obtuse lobata vel dentata, canescenti-viridis, retrorse pilosa ad adpresse pubescens. Folia caulina sessilia, auriculis semi-amplexicaulibus; lamina $10-15 \mathrm{~mm}$, glabra vel subglabra, dimidio inferiore irregulariter pinnatisecto segmentis linearibus usque lanceolatis 5-6mm longis, superiore valde dentato. Inflorescentia racemosa, ebracteata, 3-6cm, 5-30-flora. Pedicelli ascendentes, fructiferis ad $8 \mathrm{~mm}$ accrescentibus incrassatisque. Petala alba (saltem in sicco), $6.5-6.7 \times 1.5-1.7 \mathrm{~mm}$, sepalis longiora. Filamenta exappendiculata, alba, tenuia, c. $3.5 \mathrm{~mm}$; antherae flavae, c. $0.8 \mathrm{~mm}$. Nectaria duo, conspicua, mediana. Ovarium 6-8-ovulata, ovulis in quoque loculo bifariis; stigma \pm capitatum, parum bilobum. Siliquae erecto-patentes, compressae, ad maturitatem elliptico-lineares, $10-13 \times 1.5-1.7 \mathrm{~mm}$ (stylo $3-4 \mathrm{~mm}$ longo incluso), viridescentes, glabrae, valvis conspicue nervosis. Semina ovoidea, 1.3$1.5 \mathrm{~mm}$, rubro- usque atro-ferruginea, laevia, testa subtiliter reticulato-areolata; radicula accumbens. Fl. Maio.

Small perennial herb with \pm horizontal woody stock densely clothed with fibrous petiolar remains. Flowering stem erect, single, simple or sparingly branched, $7-14 \mathrm{~cm}$ tall, glabrous. Basal leaves long-petiolate, forming a distinct rosette; lamina simple, ovate, c.7-10 × 5-7mm, obtusely lobed or dentate, greyish-green, retrorsely pilose to adpressed-pubescent. Cauline leaves sessile, with semi-amplexicaul auricles; lamina $10-15 \mathrm{~mm}$, glabrous to subglabrous; lower half irregularly pinnatisect with linear to lanceolate, 5-6mm segments; upper half strongly dentate. Inflorescence racemose, ebracteate, 3-6cm, 5-30-flowered. Pedicels ascending, elongating to $8 \mathrm{~mm}$ and thickened in fruit. Petals white (at least drying white), $6.5-6.7 \times 1.5-1.7 \mathrm{~mm}$, longer than sepals. Filaments without appendages, white, slender, c. $3.5 \mathrm{~mm}$; anthers yellow, c. $0.8 \mathrm{~mm}$. Nectaries 2, conspicuous, median. Ovary 6-8-ovulate; ovules in 2 rows in each loculus; stigma \pm capitate, slightly 2-lobed. Siliquae erect-spreading, compressed, elliptic-linear at maturity, $10-13 \times 1.5-1.7 \mathrm{~mm}$ (including $3-4 \mathrm{~mm}$ style), greenish, glabrous; valves conspicuously veined. Seeds ovoid, $1.3-1.5 \mathrm{~mm}$, reddish- to blackish-brown, smooth, testa finely reticulate-areolate; radicle accumbent. Flowering May.

Type: Turkey B2 Denizli: Çivril, Akdăg, dry stony limestone slopes, c.1900m, $24 \mathrm{v}$ 1984, Y. Gemici 2690 (holo. EGE).

*Ege University, Science Faculty, Biology Department, Izmir, Turkey 


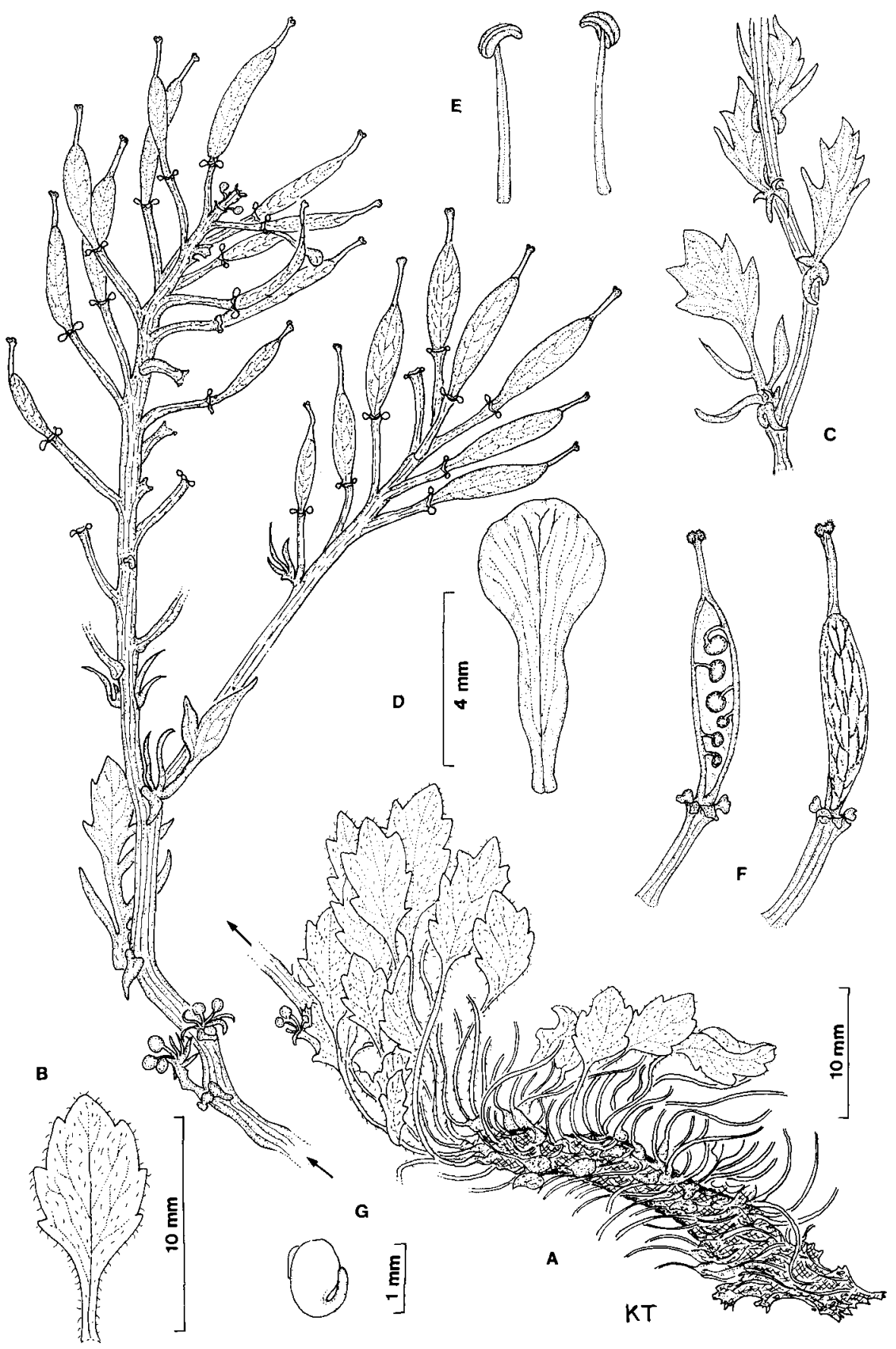

FIG. 1. A-G, Barbarea hedgeana: A, habit; B, basal leaf; C, cauline leaves; D, petal; E, stamens; F, siliquae; G, embryo. A \& C to same scale; B \& F, D \& E and G on separate scales as shown. 
In many Old World Floras where the genera Barbarea and Rorippa are treated, Barbarea is taxonomically distinguished as having seeds arranged in a single row in each loculus, and Rorippa by its seeds arranged in two rows per loculus. The seeds in $B$. hedgeana are arranged in two rows per loculus, thus resembling the condition described for the genus Rorippa. However, the siliquae valves are rather strongly veined and the style in fruit comparatively long. The overall fruiting facies is distinctive and not appropriate to a Rorippa. On the basis of the striate stem, toothed and irregularly pinnatisect cauline leaves with semi-amplexicaul auricles which are reminiscent of Barbarea, we decided to treat the new species as a Barbarea, regardless of its textbook or non-textbook position.

Out of curiosity we decided to look at the ovule arrangement in Turkish and European species of Barbarea and Rorippa. M. J. E. Coode \& J. Cullen (Flora of Turkey and the East Aegean Islands 1: 431-433 [Rorippa] and 433-438 [Barbarea], 1965), P. W. Ball (Flora Europaea 1: 281-282 [Barbarea], 1964) and D. H. Valentine (Flora Europaea 1: 283-284 [Rorippa], 1964) had all distinguished the genera according to whether the seeds were arranged in one or two rows in each loculus. 150 specimens ( 85 from Turkey) representing 13 species of Barbarea were examined. We found that this 'diagnostic' character of seed arrangement, allegedly unique to each genus, breaks down completely as every Barbarea examined had seeds in a biseriate arrangement. To our knowledge, this fact concerning Barbarea has not been previously recorded and it is evident that the alleged difference in ovule arrangement does not hold in the two genera, nor should such a character be used in a generic key. The ovule arrangement in nine species of Rorippa from Turkey and Europe which were available for comparison is identical to that found in Barbarea. Al-Shehbaz \& Rollins however $(J$. Arn. Arb. 69: 65-71, 1988), noted a uniseriate arrangement in $R$. floridana Al-Shehbaz \& Rollins and R. microphylla (Boenn. ex Reichb.) Hylander, two species occurring in North America, one indigenous, the other naturalized.

$B$. hedgeana, an East Mediterranean element, has been collected only once. It is a rare species endemic to southwest Anatolia (Pisidia). The closest ally in Turkey is undoubtedly $B$. minor $\mathrm{C}$. Koch for which three intergrading varieties have been described (Flora of Turkey and the East Aegean Islands 1: 438, 1965). B. hedgeana differs from $B$. minor in its acutely dentate-serrate basal leaves, pinnatisect cauline leaves, broader siliquae and white petals. Concerning the last character, the petals in the genus as a whole, are yellow but dry white. It is possible that $B$. hedgeana is really yellow-flowered; however, the petals were annotated as being white in vivo and also according to the memory of one of us (Y.G.).

The taxon is named in honour of Ian C. Hedge, of the Royal Botanic Garden Edinburgh who has made southwest Asian Cruciferae his special forte over many years. We are grateful to Dr Robert Mill for his help with the Latin translation and Gert Vold (Seed Bank, Copenhagen Botanic Garden) for his assistance in dissecting all the Barbarea and Rorippa fruits. 